\title{
The Crystal and Molecular Structure of Ammonium Titanyl Oxalate
}

\author{
G. M. H. VAN DE VELDE ${ }^{a}$, S. HARKEMA ${ }^{b}$ and P. J. GELLINGS ${ }^{a}$ \\ Laboratory for Inorganic Chemistry and Materials Science, Department of Chemical Engineering, Twente University \\ of Technology, Enschede ${ }^{\mathrm{a}}$, and Chemical Physics Laboratory, Twente University of Technology, Enschede ${ }^{\mathrm{b}}$, Netherlands \\ Received June 24, 1974
}

Ammonium titanyl oxalate monohydrate, $\left(\mathrm{NH}_{4}\right)_{2}$ $\mathrm{TiO}\left(\mathrm{C}_{2} \mathrm{O}_{4}\right)_{2} \cdot \mathrm{H}_{2} \mathrm{O}$, is monoclinic with cell parameters $a=13.473(2), b=11.329(1), c=17.646(2) \AA, \beta=$ $126.66(1)^{\circ}$. The space group is $P 2{ }_{1} / c$ with $Z=8$, $d_{\mathrm{c}}=1.808 \mathrm{~g} \mathrm{~cm}^{-3}$ and $d_{\mathrm{m}}=1.80 \mathrm{~g} \mathrm{~cm}^{-3}$. The crystal structure was determined from single-crystal diffractometer data and refined by least-squares methods using isotropic thermal parameters. The conventional $R$ factor was 7.0\% for 2466 used reflections.

The anions consist of cyclic tetranuclear complexes $\left[\mathrm{TiO}_{1 / 2} \mathrm{O}_{1 / 2}\left(\mathrm{C}_{2} \mathrm{O}_{4}\right)_{2}\right]_{4}{ }^{8-}$ with $\bar{I}$ symmetry. The titanium atoms are six-coordinated with two bridging oxygen atoms cis to one another and four oxygen atoms of bidentate oxalate groups, together forming a distorted octahedron. The titanium atoms of the tetramer are linked through oxygen atoms at two neighbouring apices of each octahedron. The actual name of the compound should therefore be: ammonium cyclotetra-di- $\mu$-oxo-cis-dioxalatotitanate(IV)tetrahydrate.

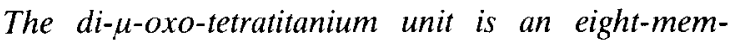
bered $-\mathrm{O}-\mathrm{Ti}-\mathrm{O}-$ ring with $\mathrm{Ti}-\mathrm{O}$ distances of succes-

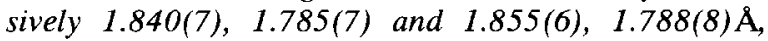
repeated by the centre of symmetry, and the orientation of the atoms suggests the presence of $d \pi-p \pi 3-$ center 2-electron bonds in each Ti-O-Ti set.

The Ti-O distances trans to the bridging oxygen atoms are much longer: 2.060(7), 2.101(7), 2.081(7) and $2.116(7) \AA$ respectively, as is to be expected from the charge displacement due to the $d \pi-p \pi$ bonding. Most $O-T i-O$ angles in the distorted octahedra differ considerably from $90^{\circ}$.

As was found by difference Fourier synthesis and thermal analysis, half of the crystal water is held very loosely compared to the other half.

\section{Introduction}

Crystal structure studies on a number of titanium(IV) complexes or organometallic compounds have shown that most of them are not monomers in the solid state. ${ }^{1}$
Well known groups of compounds with tetrameric or dimeric structure are represented by the alkoxides such as $\mathrm{Ti}\left(\mathrm{OC}_{2} \mathrm{H}_{5}\right)_{4}{ }^{2}$ and by $\beta$-diketonates such as $\mathrm{TiO}$ (acetylacetone $)_{2}{ }^{3}$ A common feature of these compounds often appears to be a cyclic $-\mathrm{O}-\mathrm{Ti}-\mathrm{O}-$ ring. Investigations of other, more inorganic, titanium(IV) compounds have not been so numerous. An example of $-\mathrm{Ti}-\mathrm{O}-\mathrm{Ti}-$ chains has been given in the case of $\mathrm{TiOSO}_{4} \cdot \mathrm{H}_{2} \mathrm{O}$.

It has never been clear whether complexes such as $\left(\mathrm{NH}_{4}\right)_{2} \mathrm{TiO}\left(\mathrm{C}_{2} \mathrm{O}_{4}\right)_{2} \cdot \mathrm{H}_{2} \mathrm{O}$ also contain such -Ti$\mathrm{O}-\mathrm{Ti}$ - chains, or have to be described as dimers or tetramers with oxo- or hydroxo bridging. Also, part of the "crystal water" might - as $-\mathrm{OH}^{-}$or $\mathrm{H}_{2} \mathrm{O}-$ take part as a ligand, as has been found in the monomeric analog $\left(\mathrm{NH}_{4}\right)_{2}\left[\mathrm{VO}\left(\mathrm{C}_{2} \mathrm{O}_{4}\right)_{2}\left(\mathrm{H}_{2} \mathrm{O}\right)\right] \cdot \mathrm{H}_{2} \mathrm{O}^{5}$

Infrared spectroscopy had shown anyhow, that the presence of a $\mathrm{Ti}=\mathrm{O}$ bond is highly improbable, as is the case in most other so-called "titanyl" complexes.

In order to obtain more information on the bonding in systems of this kind the crystal structure of $\left(\mathrm{NH}_{4}\right)_{2}$ $\mathrm{TiO}\left(\mathrm{C}_{2} \mathrm{O}_{4}\right)_{2} \cdot \mathrm{H}_{2} \mathrm{O}$ was investigated.

\section{Fxperimental}

To obtain single crystals of ammonium titanyl oxalate a direct way was chosen, which started with a cold, hydrolysed but clear solution of $\mathrm{TiCl}_{4}$ in water (about $0.5 M) .^{6}$ In this solution two equivalents of solid oxalic acid were dissolved, after which $4-5$ equivalents of ammonia were carefully added. The $\mathrm{pH}$ of the, still clear, solution should then be about $1-2$. About half the volume of ethanol was then added carefully in the course of several hours without stirring, to get two slightly mixed layers. After standing overnight, colourless crystals of $\left(\mathrm{NH}_{4}\right)_{2} \mathrm{TiO}\left(\mathrm{C}_{2} \mathrm{O}_{4}\right)_{2} \cdot \mathrm{H}_{2} \mathrm{O}$ could be isolated in a good yield (80\%).

Weissenberg photographs showed the crystals to be monoclinic. This was confirmed by measurements on a Philips PW-1100 four-circle diffractometer (MoK $\alpha$ radiation, $\lambda\left(\mathrm{K} \alpha_{1} \alpha_{2}\right) 0.7107 \AA$, graphite monochromator, $\Theta-2 \Theta$ scan method, scintillation counter, pulse height discrimination). Systematic absences found were hol 
and $0 \mathrm{k} 0$ with 1 and $k=2 n+1$ respectively. This uniquely determined the space group as $\mathrm{P} 2{ }_{1} / \mathrm{c}$.

Unit cell dimensions were determined at $20^{\circ} \mathrm{C}$ by means of the diffractometer for each of three crystals from ten averaged values of $d$ (errors given are standard deviations $\sigma): \mathrm{a}=13.473(2), \mathrm{b}=11.329(1), \mathrm{c}=$ $17.646(2) \AA, \beta=126.66(1)^{\circ}, \mathrm{V}-2160.6 \AA^{3}$.

The experimental value of the density $\mathrm{d}_{\mathrm{m}}=1.80(1)$ $\mathrm{g} \mathrm{cm}$, obtained pycnometrically in cyclohexane, agreed well with the density $\mathrm{d}_{\mathrm{c}}=1.808 \mathrm{~g} \mathrm{~cm}^{-3}$, calculated for $Z=8$ molecular units. This value, combined with the space group $\mathrm{P} 2{ }_{1} / \mathrm{c}$ meant that two independent stoichiometric units had to be expected in the unit cell, either as two monomeric, one dimeric unit, or one half of a tetramer, etc.

Using prismatic crystals (prismatic habit along [010], size about $0.3 \times 0.6 \mathrm{~mm}$ ), intensity data were collected on the diffractometer. The $\Theta-2 \Theta$ scan technique was used, with scan angle $1.2^{\circ}$ and scan rate $0.042^{\circ} \mathrm{sec}^{-1}$.

The receiving aperture was $1^{\circ}$ horizontally and vertically. Backgrounds were counted on each side of a peak during half of the scanning time. The mosaic spread was within normal limits. No absorption correction was considered necessary because the linear absorption coefficient $\mu$ is $8.8 \mathrm{~cm}^{-1}$ for this compound ( $\mathrm{MoK} \alpha$ radiation).

About 3700 independent intensities in the range $\Theta=3-25^{\circ}$ were determined, of which about 1000 reflections with $l \geqq 10$ and with weak intensities $(<0.7 \%$ of strongest reflection) were not used. For the 2709 resulting reflections, $h, k$ and $l$ were in the ranges $-14 \leqq h \leqq 12, \quad 0 \leqq k \leqq 13, \quad 0 \leqq 1 \leqq 18$. The data were reduced to $F_{o}$ values in the usual way by Lorent $z$ and polarization corrections.

Because one of the crystal water molecules Oa had a rather high thermal parameter, it was decided to perform some thermal analysis experiments. Thermogravimetric and differential thermal analysis ${ }^{12,13}$ on a Dupont thermal analyzer 900/951 suggested the disappearance of half of the crystal water below $80^{\circ} \mathrm{C}$. Unit cell dimensions were again determined in the three crystals after heating to $70-80^{\circ} \mathrm{C}$ during 12 hours (Table VII). For one of them intensities before and after heat treatment were determined and 834 reflections with $\Theta<25^{\circ}$ and $-7 \leqq \mathrm{~h} \leqq 7,0 \leqq \mathrm{k} \leqq 6$, $0 \leqq 1 \leqq 7$ were selected for reducing to $F_{o}$ values and subsequent Fourier synthesis investigation.

\section{Structure Determination and Refinement}

The structure was solved simultaneously by Patterson and direct methods. Both procedures gave the same positions for the titanium atoms. The direct methods resulted in a more distinct picture of the titanium and some oxygen atoms. Nine cycles of Fourier synthesis, using 650 strong reflections, were needed to obtain the positions of all 34 independent non-hydrogen atoms, after which eleven cycles of least-squares refinement of the positions and isotropic temperature factors were applied*. Refinement was continued until all shifts were much less than the standard deviations. In view of the fact that the main purpose of this investigation was the detcrmination of the type of complex units present in this compound, it was decided not to apply refinement with anisotropic thermal parameters, as this would have led to an extraordinary large increase of computing time.

One scale factor was used and four atomic scattering factors of $\mathrm{Ti}^{10}, \mathrm{O}, \mathrm{N}$ and $\mathrm{C}^{11}$ were applied. Anomalous dispersion and extinction influences were neglected. The function minimized was $\Sigma w\left(\left|F_{o}\right|-\left|F_{c}\right|\right)^{2}$. The weight for each reflection was $\mathrm{w}=1 / \sigma^{2}$, in which $\sigma$ was taken as $\sigma=2 \mathrm{~S}+0.01\left|\mathrm{~F}_{\mathbf{o}}\right|$, where $\mathrm{S}$ is the standard deviation in $\mathrm{F}$ due to counting statistics. Reflections with $\mathrm{I}<2 \mathrm{~S}_{\mathrm{I}}$ in which $\mathrm{S}_{\mathrm{I}}$ was the standard deviation in $I$, due to counting statistics, were treated as unobserved and were not considered in the refinement. The final $\mathrm{R}$ values after refinement were: $\mathrm{R}=\Sigma\left(|| \mathrm{F}_{\mathrm{o}} \mid\right.$ $\left.-\left|F_{c}\right| \mid\right) / \Sigma\left|F_{o}\right|=0.070, \quad R w=\left(\Sigma w\left(\left|F_{o}\right|-\left|F_{c}\right|\right)^{2} /\right.$ $\left.\Sigma w F_{o}^{2}\right)^{1 / 2}=0.092$. The number of reflections used was 2466

A final difference. Fourier synthesis did not show any significant peaks higher than $0.7 \mathrm{e} / \AA^{3}$ or $1.7 \%$ of the strongest peak. Observed and calculated structure factors are listed in Table I. The final positional and isotropic thermal parameters of 34 independent atoms are given in Table $\mathbf{I I}$.

For determining least-squares planes through the oxalate groups, the standard deviations of the fractional coordinates of the atoms were not taken into account, but the errors in the equation parameters and distances to the planes were calculated afterwards.

\section{Results and Discussion}

The compound turns out to consist of tetranuclear anions $\left[\mathrm{TiO}_{1 / 2} \mathrm{O}_{1 / 2}\left(\mathrm{C}_{2} \mathrm{O}_{4}\right)_{2}\right]_{4}{ }^{8-}$ with eight ammonium and four water groups per anion. Because of the space group $\mathrm{P} 2{ }_{1} / \mathrm{c}$ half of these are independent, so each of the two tetramers per unit cell has $\overline{1}$ symmetry. Figure 1 gives a stereoscopic view of the unit cell, in which four full tetramers are drawn for clarity.

I Ialf a tetramer, as illustrated ${ }^{15}$ in Figure 2, consists of two distorted octahedra of oxygen atoms around the titanium atoms Ti1 and Ti2, which share the bridging atom $\mathrm{O} 5$. The 1 antipod of $\mathrm{Ti} 2$ shares oxygen atom 06 with Til while the 1 antipod of Til shares

* All computations were performed on a I.B.M. 360/50 using the crystallographic program system of Twente University of Technology ${ }^{7}$, which contains modified versions of MAGIC $^{8}$ and ORFLS ${ }^{9}$. 
TABLE I. Observed and calculated structure factors $F_{o}$ and $\left|F_{c}\right|$.

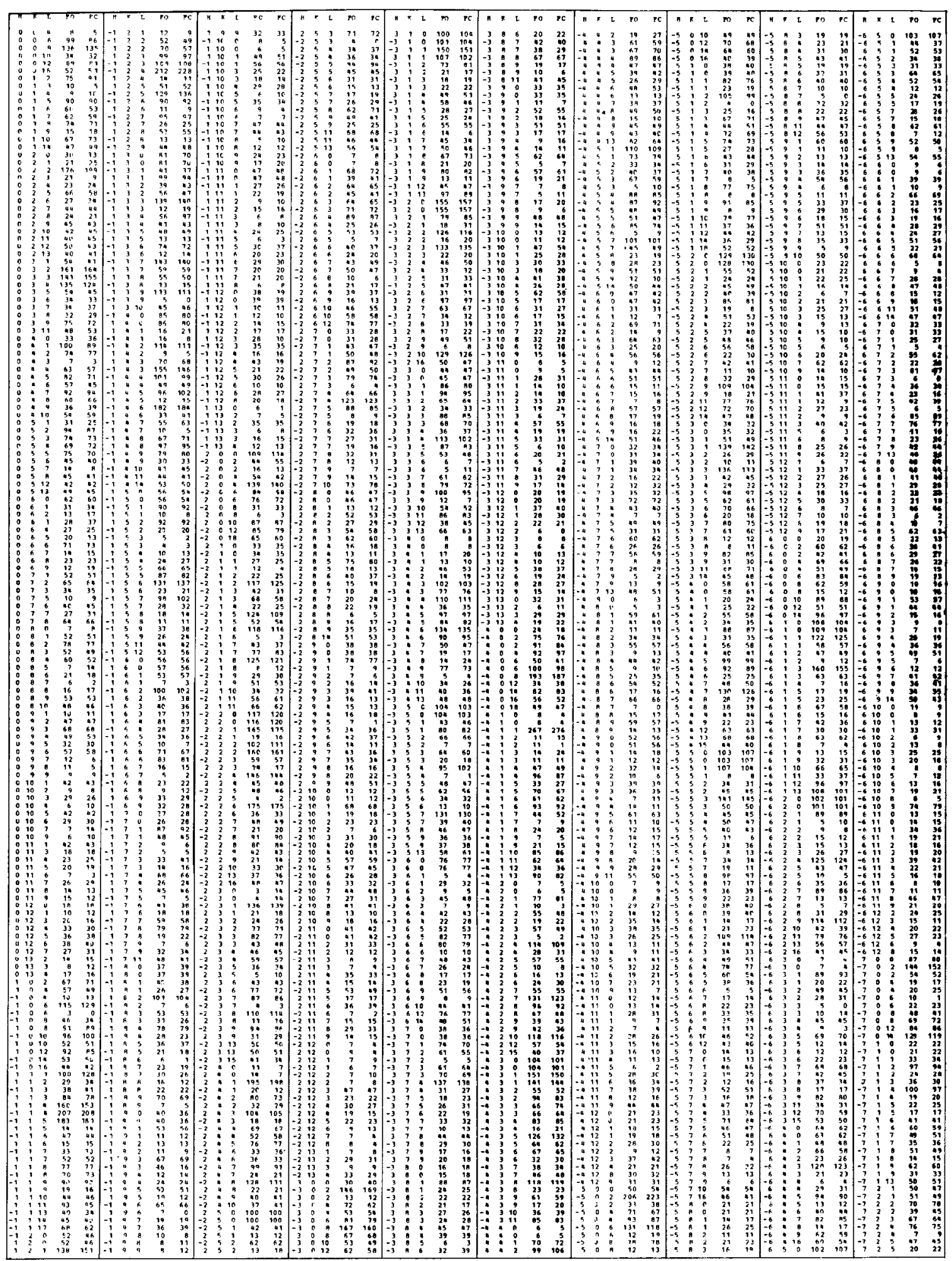


TABLE I (Cont)

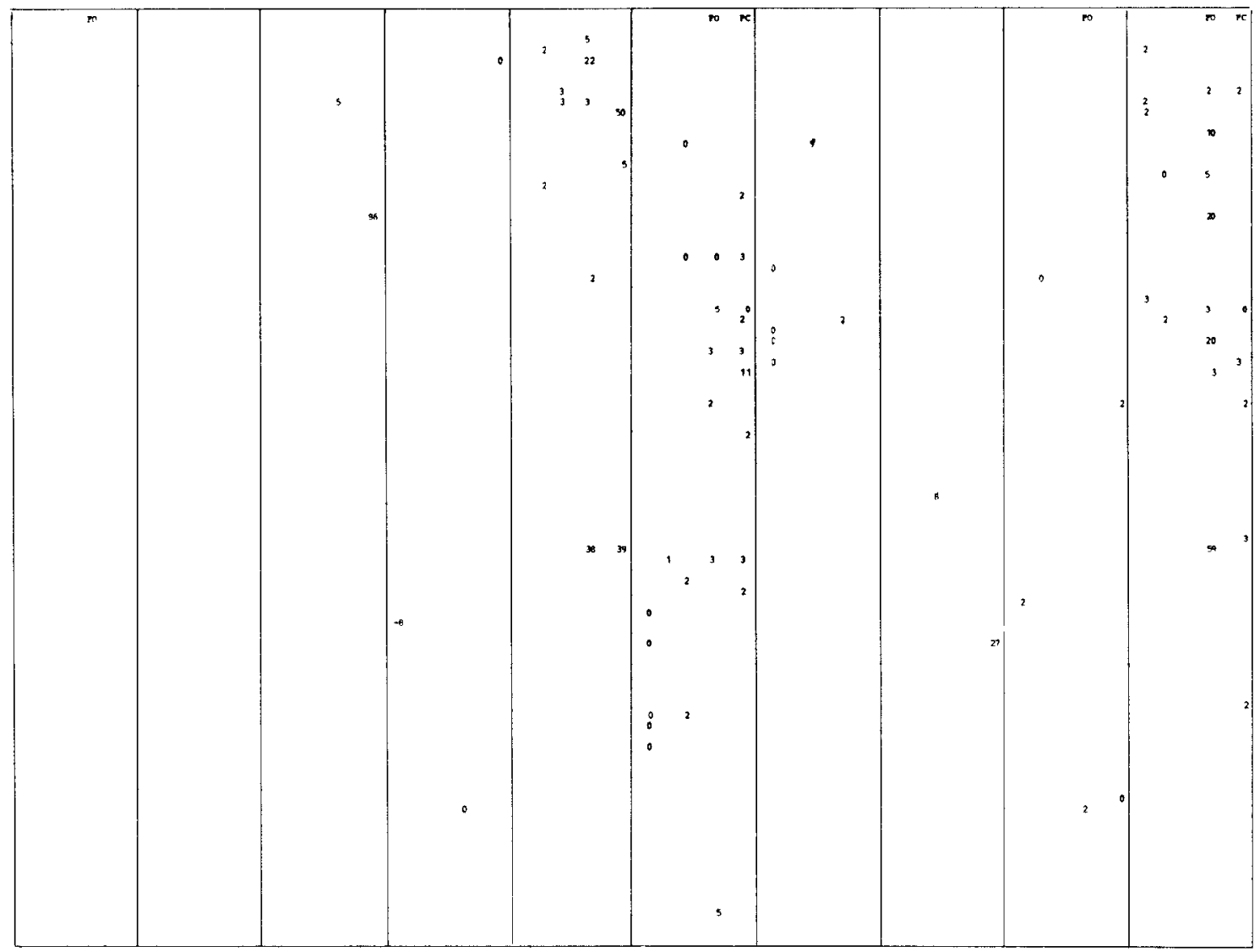
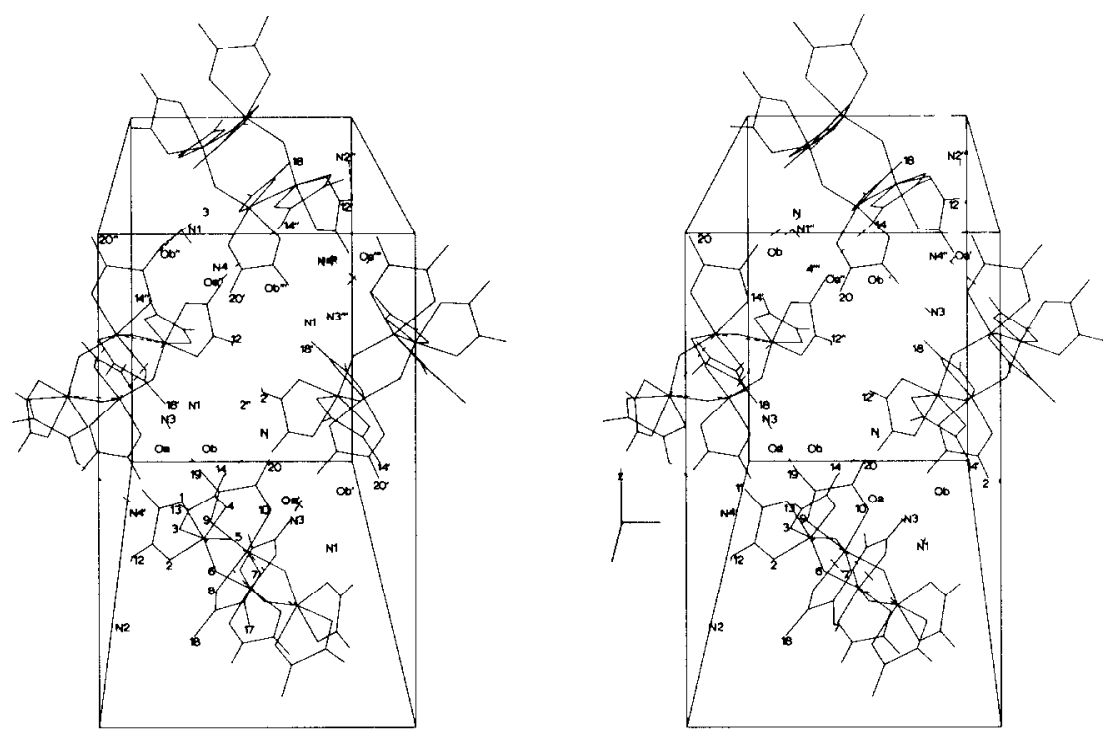

Figure 1 Stereoscopic view ${ }^{14}$ of the unit cell with complete tetramers ammonium and water groups 
TABLE II. Non-hydrogen Fractional Atomic Coordinates, Isotropic Temperature Factors and Standard Deviations of the Last Digit (in parentheses).*

\begin{tabular}{lllrllllll}
\hline & X & Y & \multicolumn{1}{c}{ Z } & B & & X & Y & Z & B \\
\hline Ti1 & $3963(1)$ & $3261(1)$ & $0177(1)$ & $144(3)$ & Ti2 & $6760(1)$ & $4840(1)$ & $1586(1)$ & $141(3)$ \\
O1 & $4498(4)$ & $2411(4)$ & $1427(4)$ & $194(9)$ & O7 & $8668(4)$ & $5185(4)$ & $2303(4)$ & $191(9)$ \\
O2 & $5007(4)$ & $1964(4)$ & $0285(4)$ & $221(10)$ & O8 & $7224(4)$ & $3733(4)$ & $0972(4)$ & $216(9)$ \\
O3 & $2390(4)$ & $2234(4)$ & $-0523(4)$ & $193(9)$ & O9 & $7301(4)$ & $3523(4)$ & $2585(4)$ & $214(10)$ \\
O4 & $2844(4)$ & $4187(4)$ & $0343(4)$ & $205(9)$ & O10 & $6882(4)$ & $5706(4)$ & $2610(4)$ & $204(9)$ \\
O5 & $5184(4)$ & $4363(4)$ & $0899(4)$ & $190(9)$ & O6”* & & & & \\
O6 & $3532(4)$ & $3756(4)$ & $-0943(4)$ & $186(9)$ & O5 & & & & \\
C1 & $5245(6)$ & $1537(6)$ & $1700(6)$ & $193(13)$ & C7 & $9200(6)$ & $4608(6)$ & $2026(6)$ & $201(13)$ \\
C2 & $5637(6)$ & $1346(7)$ & $1066(6)$ & $247(15)$ & C8 & $8347(6)$ & $3680(7)$ & $1266(6)$ & $242(15)$ \\
O11 & $5693(5)$ & $0970(5)$ & $2423(4)$ & $304(11)$ & O17 & $10284(5)$ & $4723(5)$ & $2285(4)$ & $297(11)$ \\
O12 & $6493(5)$ & $0669(5)$ & $1295(4)$ & $369(13)$ & O18 & $8751(5)$ & $2972(5)$ & $0972(5)$ & $416(13)$ \\
C3 & $1492(6)$ & $2613(6)$ & $-0532(6)$ & $209(14)$ & C9 & $7344(6)$ & $3830(7)$ & $3295(6)$ & $223(14)$ \\
C4 & $1792(7)$ & $3726(6)$ & $0036(6)$ & $240(14)$ & C10 & $7195(7)$ & $5133(7)$ & $3348(6)$ & $277(15)$ \\
O13 & $0470(5)$ & $2165(5)$ & $-0973(4)$ & $391(13)$ & O19 & $7555(5)$ & $3145(5)$ & $3917(4)$ & $364(12)$ \\
O14 & $1089(5)$ & $4126(5)$ & $0197(5)$ & $397(13)$ & O20 & $7415(6)$ & $5601(6)$ & $4060(5)$ & $486(15)$ \\
N1 & $1610(6)$ & $2742(6)$ & $2287(5)$ & $378(16)$ & N3 & $5731(6)$ & $1884(6)$ & $3982(5)$ & $313(14)$ \\
N2 & $8111(6)$ & $0451(6)$ & $0753(5)$ & $353(15)$ & N4 & $1510(6)$ & $6033(6)$ & $1459(5)$ & $356(15)$ \\
Oa & $0174(7)$ & $1367(8)$ & $0557(6)$ & $778(22)$ & Ob & $3827(5)$ & $3505(5)$ & $2539(4)$ & $341(12)$
\end{tabular}

* Atomic coordinates are $\times 10^{4}$, thermal parameters $\times 10^{2}\left(\AA^{2}\right)$; B is the coefficient in the expression exp[-B $\left.\sin ^{2} \theta / \lambda^{2}\right]$. The prime index ("') means the transformation $1 \mathrm{x}, 1 \mathrm{y}, \mathrm{z}$ of the coordinates $\mathrm{x}, \mathrm{y}, \mathrm{z}$ (centre of symmetry in point $1 / 2,1 / 2,0)$. In general the following indices will be used, in order of increasing $\mathrm{z}$ : () $\mathrm{x}, \mathrm{y}, \mathrm{z},\left(^{\prime}\right) 1-\mathrm{x}, 1 / 2+\mathrm{y}, 1 / 2-\mathrm{z}$, (") $\dot{x}, 1 / 2-y, 1 / 2+z,\left(^{\prime \prime \prime}\right) 1-x, 1-y, 1-z$, which represent the atoms of the halves of the four tetramers that are mainly within the unit cell depicted in Figure 1.

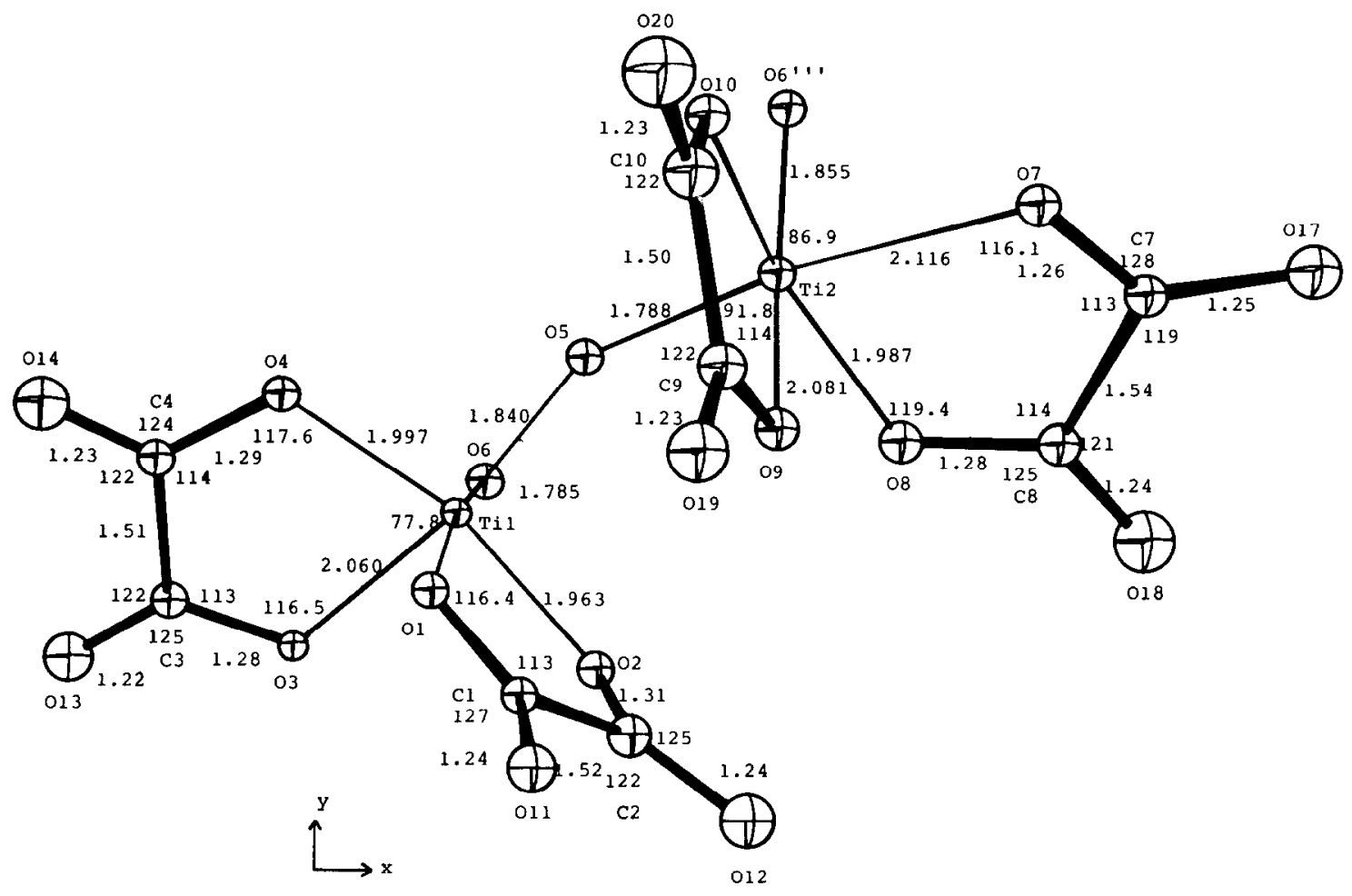

Figure 2. Configuration of the half tetramer, drawn by ORTEP. ${ }^{15}$ 
TABLE III. Bond Lengths $(\AA)$ and Bond Angles in the Two Distorted Octahedra and in the -O-Ti-O- Eightmembered Ring.*

\begin{tabular}{|c|c|c|c|c|c|c|c|}
\hline $\mathrm{Ti1}-\mathrm{O} 1$ & $2.101(7)$ & $\mathrm{Ti2}-\mathrm{O} 7$ & $2.116(7)$ & $\mathrm{O} 2-\mathrm{Ti1}-\mathrm{O} 3$ & $93.2(3)$ & $\mathrm{O} 8-\mathrm{Ti} 2-\mathrm{O} 9$ & $86.8(3)$ \\
\hline $\mathrm{Ti} 1-\mathrm{O}_{2}$ & $1.963(7)$ & $\mathrm{Ti} 2-\mathrm{O} 8$ & $1.987(7)$ & $\mathrm{O} 2-\mathrm{Ti} 1-\mathrm{O} 4$ & $159.9(12)$ & $\mathrm{O} 8-\mathrm{Ti2}-\mathrm{O} 10$ & $158.6(12)$ \\
\hline Til-O3 & $2.060(7)$ & $\mathrm{Ti} 2-\mathrm{O} 9$ & $2.081(7)$ & $\mathrm{O} 2-\mathrm{Ti1}-\mathrm{O} 5$ & $98.5(3)$ & $\mathrm{O} 8-\mathrm{Ti} 2-\mathrm{O} 6^{\prime \prime \prime}$ & $103.2(3)$ \\
\hline Ti1 $-\mathrm{O} 4$ & $1.997(7)$ & $\mathrm{Ti} 2-\mathrm{O} 10$ & $1.975(7)$ & $\mathrm{O} 2-\mathrm{Ti} 1-\mathrm{O} 6$ & $94.8(3)$ & O8-Ti2-O5 & $94.2(3)$ \\
\hline $\mathrm{Ti1}-\mathrm{O} 5$ & $1.840(7)$ & $\mathrm{Ti} 2-\mathrm{O} 6^{\prime \prime \prime}$ & $1.855(6)$ & O3-Ti1-O4 & $77.8(3)$ & O9-Ti2-O10 & $77.6(3)$ \\
\hline Ti1-O6 & $1.785(7)$ & $\mathrm{Ti} 2-\mathrm{O} 5$ & $1.788(8)$ & O3-Ti1-O5 & $166.6(12)$ & O9-Ti2-O6"' & $166.5(12)$ \\
\hline $\mathrm{O} 1-\mathrm{Ti} 1-\mathrm{O} 2$ & $77.2(3)$ & O7-Ti2-O 8 & $77.1(3)$ & O3-Ti1-O6 & $88.6(3)$ & O9-Ti2-O5 & $91.8(3)$ \\
\hline $\mathrm{O} 1-\mathrm{Ti1}-\mathrm{O} 3$ & $87.5(3)$ & O7-Ti2-O9 & $86.6(3)$ & O4-Ti1-O5 & $89.0(3)$ & $\mathrm{O} 10-\mathrm{Ti2}-\mathrm{O} 6^{\prime \prime \prime}$ & $90.3(3)$ \\
\hline O1-Ti1-O4 & $84.4(3)$ & $\mathrm{O} 7-\mathrm{Ti2}-\mathrm{O} 10$ & $87.3(3)$ & O4-Ti1-O6 & $102.9(3)$ & O10-Ti2-O5 & $100.8(3)$ \\
\hline O1-Ti1-O5 & $88.8(3)$ & $\mathrm{O} 7-\mathrm{Ti2}-\mathrm{O} 6^{\prime \prime \prime}$ & $86.9(3)$ & O5-Ti1-O6 & $96.8(3)$ & $\mathrm{O} 6^{\prime \prime \prime}-\mathrm{Ti} 2-\mathrm{O} 5$ & $96.4(3)$ \\
\hline O1-Ti1-O6 & $170.8(12)$ & $\mathrm{O} 7-\mathrm{Ti} 2-\mathrm{O} 5$ & $171.2(12)$ & & & & \\
\hline $\mathrm{Ti} 1-\mathrm{Ti} 2$ & $3.521(2)$ & Ti1-Ti1"' & $5.080(2)$ & Ti2 Ti1 - Ti2"' & $85.76(5)$ & Ti1-Ti2-Ti1"' & $94.24(5)$ \\
\hline Ti1-Ti2"' & $3.411(2)$ & $\mathrm{Ti} 2-\mathrm{Ti} 2^{\prime \prime \prime}$ & $4.717(2)$ & $\mathrm{Ti} 1-\mathrm{O} 5-\mathrm{Ti} 2$ & $152.1(5)$ & $06-05-06^{\prime \prime \prime}$ & $106.6(4)$ \\
\hline O5-O6 & $2.712(9)$ & $\mathrm{O} 5-05^{\prime \prime \prime}$ & $3.243(9)$ & Ti1-O6-Ti2" & $139.2(4)$ & $\mathrm{O} 5-\mathrm{O} 6-\mathrm{O} 5^{\prime \prime \prime}$ & $73.4(3)$ \\
\hline $\mathrm{O} 5-\mathrm{O} 6^{\prime \prime \prime}$ & $2.717(9)$ & $06-06^{\prime \prime \prime}$ & $4.353(9)$ & & & & \\
\hline
\end{tabular}

* The use of standard deviations and of the prime index ("') is the same as in Table II.

atom $06 "$ " (the $\overline{1}$ antipod of 06 ) with Ti2. In this way the anion is a cyclo-tetra-di- $\mu$-oxo-cis-dioxalato titanate(IV). It is interesting to note that this structure with an eight-membered ring is novel for Ii(IV) complexes, as such rings in other compounds have different features: in the example of $\left[\mathrm{Ti}\left(\mathrm{OC}_{2} \mathrm{H}_{5}\right)_{4}\right]_{4}{ }^{2}$ the octahedra share edges instead of apices, so the bridging oxygen atoms are both two- and three-coordinated. In $\left[\left(\pi-\mathrm{C}_{5} \mathrm{H}_{5}\right) \mathrm{TiClO}\right]_{4}{ }^{16}$ the eight-membered ring consists of tetrahedra sharing apices.

Bond angles and interatomic distances within the above mentioned octahedra and eight-membered ring are given in Table III. This ring is not planar, but because of the crystallographic symmetry consists of two intersecting planes, one of titanium and one of oxygen atoms. The titanium atoms Til and Ti1" lie, within experimental error, in the oxygen plane (distances to the plane +0.001 and $-0.001 \AA$ respectively).

In the first plane the $\mathrm{Ti}$ atoms nearly form a square (see Figure 3) with sides of 3.521(2) and 3.411(2) $\AA$ and angles of $85.76(5)$ and $94.24(5)$ degrees. The four oxygen atoms practically form a diamond with sides of $2.712(9), 2.717(9) \AA$ and angles of $106.6(4)$ and 73.4(3) degrees. The angle between the two planes is $20.73^{\circ}$. The oxygen plane is oriented through the other plane in such a way that one diagonal of the diamond is shorter and the other longer than the sides of the square formed by the $\mathrm{Ti}$ atoms. The torsion angles of the ring were found to be $-92.5,-43.2,+71.1$, $-127.6,+92.5^{\circ}$, etc., around the bonds O5-Ti1, Ti1-06, O6-Ti2"', etc. The ring thus shows a peculiar kind of "chair" configuration.

The Ti-O distances in the ring are short: $1.840(7)$, $1.785(7)$ and $1.855(6), 1.788(8) \AA$ alternatingly, which suggests a fair amount of $d \pi-p \pi$ bonding. $\Lambda$ model has suggested that three-center two-electron bonds in each of the four $\mathrm{Ti}-\mathrm{O}-\mathrm{Ti}$ sets are quite pos-

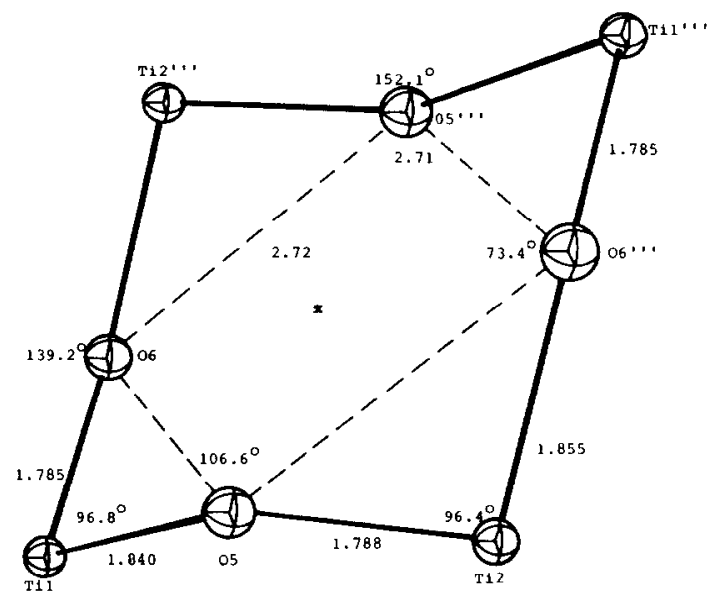

Figure 3. The eight-membered ring of the tctramer.

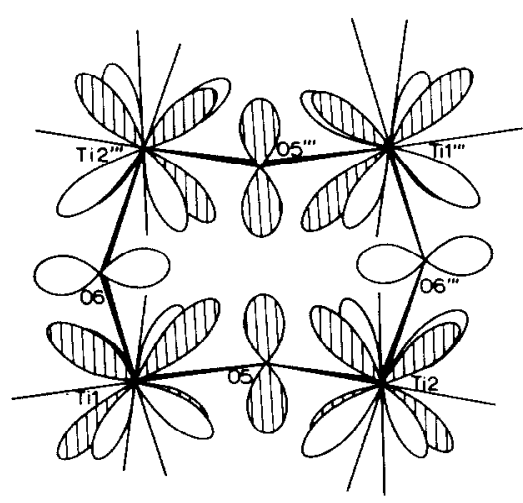

Figure 4. Possible $d \tau-\mathrm{p} \pi$ 3-center 2 -electron bonds in $\mathrm{Ti}-\mathrm{O}-\mathrm{Ti}$ sets of the eight-ring (shaded and unshaded areas). 
sible. An outline which emphasizes the spatial configuration of the ring and these bonds is given in Figure 4. The angles Ti1-O5-Ti2 and Ti1-O6-Ti2"' are 152.1(5), and 139.2(4) degrees, respectively. In a simplified picture of nonequivalent hybrid orbitals ${ }^{17}$ the bridging oxygen atom could then have $\sigma$-bonds with two titanium atoms using two $s p^{1.13}$ or $s p^{1.32}$ hybrid orbitals, respectively.

For maximum overlap in the $\pi$-molecular orbitals it is to be expected that the $\mathrm{O}-\mathrm{Ti}-\mathrm{O}$ angles in the ring are greater than $90^{\circ}$, as they indeed are: O5-Ti1-O6 $96.8(3)^{\circ}$ and $06^{\prime \prime \prime}-\mathrm{Ti} 2-\mathrm{O} 5$ 96.4(3) ${ }^{\circ}$. The unequal $\mathrm{Ti}-\mathrm{O}$ distances within each $\mathrm{O}-\mathrm{Ti}-\mathrm{O}$ set are due to the orientation of the orbitals, which chonses an optimum in which more perfectly parallel $\pi$-orbital pairs alternate with less perfectly parallel pairs. As could also be expected from charge displacement effects, the $\mathrm{Ti}-\mathrm{O}$ distances trans to the bridging oxygen atoms are much longer, 2.060(7), 2.101(7), 2.081(7) and 2.116(7) $\AA$ (for the bonds between Til and $\mathrm{O} 3, \mathrm{O} 1$ and between $\mathrm{Ti} 2$ and $\mathrm{O} 9, \mathrm{O} 7$ respectively). The magnitude of this trans effect within the pairs $\mathrm{Ti} 1-\mathrm{O} 3, \mathrm{O} 1$ and $\mathrm{Ti} 2-\mathrm{O} 9$, $\mathrm{O} 7$ is not directly related to the bond lengths in the ring, but the differences within the opposite pairs are probably too small to give a distinct effect.

The octahedral coordination around the titanium atom is severely distorted. Angles expected to be $90^{\circ}$ in a perfect octahedron vary from 77 to $103^{\circ}$ and the angles expected to be $180^{\circ}$ differ from this by as much as $21^{\circ}$. As could be expected from the unequal shortening of the Ti-bridge oxygen bonds, the distortion is not simply digonal, which is well illustrated by the widely different angles O1-Ti1-O2 of 77.2(3) ${ }^{\circ}$ and
O3-Ti1-O2 of $93.2(3)^{\circ}$, or its analogs in the other octahedron of $77.1(3)^{\circ}$ and $86.8(3)^{\circ}$. The titanium atom is most nearly coplanar with the four oxygen atoms $\mathrm{O} 1, \mathrm{O} 2, \mathrm{O} 6$ and $\mathrm{O} 4$ (sum of equatorial angles $359.3^{\circ}$ ), in the other octahedron with $\mathrm{O} 7, \mathrm{O} 8$, O5 and $\mathrm{O} 10$ (sum of equatorial angles $359.4^{\circ}$ ).

In Table IV the bond lengths and angles in the four oxalate groups together with some other relevant details are grouped in such a way that another trans effect is easily observed. Speaking in general terms a "short" $\mathrm{Ti}-\mathrm{O}$ distance leads to a "long" $\mathrm{O}-\mathrm{C}$ distance which in turn leads to a shorter $\mathrm{C}$-terminal $\mathrm{O}$ distance. This effect also explains that $\mathrm{C} 1-\mathrm{O} 11$, corresponding to a long Ti1-O1 distance, is longer than $\mathrm{C} 2-\mathrm{O} 12$, corresponding to a short $\mathrm{Ti}-\mathrm{O} 2$ distance. However, $\mathrm{C} 4-\mathrm{O} 14$ is longer than $\mathrm{C} 3-\mathrm{O} 13$, but apart from the large standard deviations which make this particular case disputable, this might be caused by hydrogen bonding with $\mathrm{NI}_{4}{ }^{+}$. For comparison of the general trend of distances and angles in these oxalates, two other typical oxalate compounds are included in Table IV; one is ammonium uranyl trioxalate, ${ }^{\mathbf{1 8}}$ an example of a metal-oxo oxalate complex in which the oxalate group has approximately the same features but is apparently more symmetric, due to the absence of "opposite" unequal metal-oxygen bonds. The other example is an acidic oxalate ${ }^{19}$ in which the oxalate group is even more unsymmetrical than in the titanyl oxalate complex, due to the combination of the $\mathrm{OH}$ bond and hydrogen bonding to oxalate oxygen atoms. The carbon and oxygen atoms in the acidic oxalate are in a planar arrangement, in contrast to the four oxalate groups in Table IV.

TABLE IV. Bond Lengths $(\AA)$ and Angles (deg) in the Four Oxalate Chelates.

\begin{tabular}{|c|c|c|c|c|c|c|c|c|}
\hline $\mathrm{n}^{*}$ & $\mathrm{C} 1-\mathrm{O} 11$ & $\mathrm{C} 1-\mathrm{O} 1$ & Ti O1 & $\mathrm{O} 11-\mathrm{C} 1-\mathrm{O} 1$ & $\mathrm{O} 11-\mathrm{C} 1-\mathrm{C} 2$ & $\mathrm{O} 1-\mathrm{C} 1-\mathrm{C} 2$ & $\mathrm{Ti}-\mathrm{O} 1-\mathrm{C} 1$ & $\mathrm{C} 1-\mathrm{C} 2$ \\
\hline 0 & $1.241(10)$ & $1.252(10)$ & 2.101 & $126.8(10)$ & $119.7(10)$ & $113.5(9)$ & $116.4(7)$ & $1.517(14)$ \\
\hline 2 & $1.216(12)$ & $1.275(12)$ & 2.060 & $124.8(10)$ & $121.7(10)$ & $113.4(9)$ & $116.5(7)$ & $1.508(11)$ \\
\hline 6 & $1.250(13)$ & $1.264(11)$ & 2.116 & $127.8(11)$ & $119.3(10)$ & $112.8(9)$ & $116.1(7)$ & $1.544(12)$ \\
\hline 8 & $1.231(11)$ & $1.268(11)$ & 2.081 & $123.9(10)$ & $122.2(10)$ & $113.8(9)$ & $115.3(7)$ & $1.500(12)$ \\
\hline a & 1.22 & 1.26 & & 129 & 119 & 112 & & 1.56 \\
\hline b & 1.257 & 1.236 & & 127.17 & 114.40 & 118.43 & & 1.549 \\
\hline $\mathrm{n}$ & $\mathrm{C} 2-\mathrm{O} 12$ & $\mathrm{C} 2-\mathrm{O} 2$ & $\mathrm{Ti}-\mathrm{O} 2$ & $\mathrm{O} 12-\mathrm{C} 2-\mathrm{O} 2$ & $\mathrm{O} 12-\mathrm{C} 2-\mathrm{C} 1$ & $\mathrm{O} 2-\mathrm{C} 2-\mathrm{C} 1$ & $\mathrm{Ti}-\mathrm{O} 2-\mathrm{C} 2$ & \\
\hline 0 & $1.235(12)$ & $1.309(10)$ & 1.963 & $124.7(10)$ & $122.2(10)$ & $113.2(9)$ & $118.6(7)$ & \\
\hline 2 & $1.227(14)$ & $1.288(12)$ & 1.997 & $124.1(10)$ & $121.7(10)$ & $114.2(9)$ & $117.6(8)$ & \\
\hline 6 & $1.243(12)$ & $1.275(12)$ & 1.987 & $124.7(11)$ & $121.2(10)$ & $114.1(9)$ & $119.4(7)$ & \\
\hline 8 & $1.226(12)$ & $1.280(11)$ & 1.975 & $123.7(10)$ & $122.0(11)$ & $114.2(9)$ & $118.4(8)$ & \\
\hline $\mathbf{a}$ & 1.22 & 1.26 & & 127 & 119 & 115 & & \\
\hline $\mathrm{b}$ & 1.204 & 1.304 & & 125.29 & 121.61 & 113.10 & & \\
\hline
\end{tabular}

* Corresponding bonds and angles are grouped together. The headings C1-O11 etc. should actually be read as $\mathrm{C}(1+\mathrm{n})-\mathrm{O}(11+\mathrm{n})$ etc., in which the running number $\mathrm{n}$ takes four different values for the oxalate groups Til-O1, O2; $\mathrm{Ti1}-\mathrm{O} 3, \mathrm{O} 4 ; \mathrm{Ti} 2-\mathrm{O} 7, \mathrm{O} 8 ; \mathrm{Ti2}-\mathrm{O} 9, \mathrm{O} 10$. For comparison data of two other more or less asymmetric oxalate groups are added: $a,\left(\mathrm{NH}_{4}\right)_{4} \mathrm{UO}_{2}\left(\mathrm{C}_{2} \mathrm{O}_{4}\right)_{3}{ }^{18}$ and $b, \mathrm{NH}_{4} \mathrm{HC}_{2} \mathrm{O}_{4} \cdot{ }^{1} /{ }_{2} \mathrm{H}_{2} \mathrm{O}^{19}$ 
TABLE V. Least-squares Planes through the Oxalate Groups.*

\begin{tabular}{|c|c|c|c|c|c|c|c|c|c|c|c|c|}
\hline \multirow{2}{*}{$\begin{array}{l}\text { Nr. of } \\
\text { plane } \\
11\end{array}$} & \multirow{2}{*}{$\begin{array}{l}\text { A } \\
\text { (for } 6,7\end{array}$} & \multirow{2}{*}{ B } & \multirow{2}{*}{$\begin{array}{l}\text { C } \\
\text { ctively) }\end{array}$} & \multirow[t]{2}{*}{$\mathrm{D}$} & \multirow[t]{2}{*}{$\Sigma$} & \multicolumn{7}{|c|}{ Displacements of 6,7 atoms resp. $(\AA)$} \\
\hline & & & & & & $\overline{\mathrm{Ti}}$ & $\begin{array}{l}\mathrm{C} \\
(1+n)\end{array}$ & $\begin{array}{l}\mathrm{C} \\
(2+n)\end{array}$ & $\begin{array}{l}\mathrm{O} \\
(1+n)\end{array}$ & $\begin{array}{l}\mathrm{O} \\
(2+n)\end{array}$ & $\begin{array}{l}\mathrm{O} \\
(11+n)\end{array}$ & $\begin{array}{l}\mathrm{O} \\
(12+n)\end{array}$ \\
\hline 0 & $\begin{array}{l}-.5158 \\
-.5318\end{array}$ & $\begin{array}{l}-.7004 \\
-.6703\end{array}$ & $\begin{array}{l}-.4906 \\
-.5176\end{array}$ & $\begin{array}{l}5.176 \\
5.269\end{array}$ & $\begin{array}{l}.026 \\
.026\end{array}$ & -.078 & $\begin{array}{l}.012 \\
.023\end{array}$ & $\begin{array}{l}.012 \\
.024\end{array}$ & $\begin{array}{l}-.091 \\
-.031\end{array}$ & $\begin{array}{l}.078 \\
.141\end{array}$ & $\begin{array}{l}.070 \\
.035\end{array}$ & $\begin{array}{l}-.082 \\
-.115\end{array}$ \\
\hline 2 & $\begin{array}{l}-.1405 \\
-.1531\end{array}$ & $\begin{array}{l}-.5563 \\
-.5568\end{array}$ & $\begin{array}{l}.8190 \\
.8164\end{array}$ & $\begin{array}{l}2.636 \\
2.664\end{array}$ & $\begin{array}{l}.033 \\
.034\end{array}$ & .023 & $\begin{array}{l}.011 \\
.008\end{array}$ & $\begin{array}{l}-005 \\
-.008\end{array}$ & $\begin{array}{l}.091 \\
.073\end{array}$ & $\begin{array}{l}-.093 \\
-.112\end{array}$ & $\begin{array}{l}-.090 \\
-.080\end{array}$ & $\begin{array}{l}.086 \\
.096\end{array}$ \\
\hline 6 & $\begin{array}{l}-.2119 \\
-.2150\end{array}$ & $\begin{array}{l}-.6643 \\
-.6633\end{array}$ & $\begin{array}{l}.7168 \\
.7168\end{array}$ & $\begin{array}{l}3.593 \\
3.621\end{array}$ & $\begin{array}{l}.019 \\
.019\end{array}$ & -.006 & $\begin{array}{l}.007 \\
.008\end{array}$ & $\begin{array}{l}.008 \\
.009\end{array}$ & $\begin{array}{l}.067 \\
.072\end{array}$ & $\begin{array}{l}-.075 \\
-.071\end{array}$ & $\begin{array}{l}-.068 \\
-.071\end{array}$ & $\begin{array}{l}.062 \\
.059\end{array}$ \\
\hline 8 & $\begin{array}{l}-.8876 \\
-.8909\end{array}$ & $\begin{array}{l}-.1336 \\
-.1346\end{array}$ & $\begin{array}{l}-.4407 \\
-.4338\end{array}$ & $\begin{array}{l}8.360 \\
8.351\end{array}$ & $\begin{array}{l}.030 \\
.031\end{array}$ & .014 & $\begin{array}{l}.023 \\
.021\end{array}$ & $\begin{array}{l}.021 \\
.019\end{array}$ & $\begin{array}{l}-.100 \\
-.111\end{array}$ & $\begin{array}{l}.079 \\
.068\end{array}$ & $\begin{array}{l}.068 \\
.075\end{array}$ & $\begin{array}{l}-.091 \\
-.086\end{array}$ \\
\hline
\end{tabular}

* The equation used is $\mathrm{Ax}+\mathrm{By}+\mathrm{Cz}-\mathrm{D}=0$, where $\mathrm{A}, \mathrm{B}$ and $\mathrm{C}$ are direction cosines and $\mathrm{D}$ is the perpendicular distance from the origin to the plane. $\Sigma$ is the sum of the squares of the deviations of the atoms from the plane. The equation is related to a Cartesian $\AA$ coord inate system with $\mathrm{z}$ in the ac-plane and $\mathrm{x}$ and $\mathrm{y}$ along the $\mathrm{a}$ - and $\mathrm{b}$-axis respectively. The approximate standard deviations are: in $\mathrm{A}-\mathrm{C} \pm 0.0005$, in $\mathrm{D} \pm 0.004$, in $\mathrm{Ti} \pm 0.002, \mathrm{C} \pm 0.009, \mathrm{O} \pm 0.006-0.007$.

TABLE VI. Hydrogen Bond Distances $(\AA)$ and Angles (deg) of $\mathrm{NH}_{4}{ }^{+}$and $\mathrm{H}_{2} \mathrm{O} .^{*}$

\begin{tabular}{|c|c|c|c|c|c|c|c|}
\hline Distance & & $\begin{array}{l}\text { Augle } \\
\text { symbol }\end{array}$ & Angle & Dislante & & $\begin{array}{l}\text { Angle } \\
\text { symbol }\end{array}$ & Angle \\
\hline $\mathrm{N} 1-\mathrm{O} 17^{\mathrm{a}}$ & 2.867 & $17-\mathrm{N}-\mathrm{b}$ & 110.7 & N3-O19 & 2.903 & $19-\mathrm{N}-11$ & 71.1 \\
\hline $\mathrm{N} 1-\mathrm{Ob}$ & 2.878 & $17-\mathrm{N}-\mathrm{a}$ & 113.3 & $\mathrm{~N} 3-\mathrm{O} 11$ & 2.911 & $19-N-b$ & 88.9 \\
\hline $\mathrm{N} 1-\mathrm{Oa}$ & 2.905 & $\mathrm{~b}-\mathrm{N}-\mathrm{a}$ & 107.6 & $\mathrm{~N} 3-\mathrm{Ob}$ & 2.939 & $11-\mathrm{N}-\mathrm{b}$ & 83.7 \\
\hline $\mathrm{N} 2-\mathrm{O} 20^{\prime \prime e}$ & 2.807 & $20-N-12$ & 123.7 & $\mathrm{~N} 4-\mathrm{O} 14$ & 2.905 & $14-\mathrm{N}-14^{\prime \prime \prime}$ & 67.7 \\
\hline $\mathrm{N} 2-\mathrm{O} 12$ & 2.867 & $20-N-17$ & 133.4 & $\mathrm{~N} 4-\mathrm{O} 14^{\prime \prime \prime h}$ & 2.935 & $14-\mathrm{N}-19$ & 110.1 \\
\hline $\mathrm{N} 2-\mathrm{O} 17^{\prime \mathrm{C}}$ & 2.899 & $20-N-18$ & 116.0 & $\mathrm{~N} 4-\mathrm{O} 19^{\prime}$ & 2.958 & $14^{\prime \prime \prime}-\mathrm{N}-19$ & 104.0 \\
\hline \multirow[t]{3}{*}{$\mathrm{N} 2-\mathrm{O} 18$} & 2.941 & $12-\mathrm{N}-17$ & 78.4 & $\left(\mathrm{~N} 4-\mathrm{O} 11^{\prime}\right.$ & $3.037)$ & & \\
\hline & & $12-\mathrm{N}-18$ & 95.4 & $\left(\mathrm{~N} 4-\mathrm{O} 13^{\prime \prime h}\right.$ & $3.048)$ & & \\
\hline & & $17-N-18$ & 99.7 & & & & \\
\hline $\mathrm{Oa}-\mathrm{N} 1$ & 2.905 & $\mathrm{~N}-\mathrm{O}-20$ & 88.1 & $\mathrm{Ob}-\mathrm{O} 11^{\prime}$ & 2.858 & $11-\mathrm{O}-\mathrm{N} 1$ & 119.8 \\
\hline$\left(\mathrm{Oa}-\mathrm{O} 20^{\prime \mathrm{d}}\right.$ & $3.023)$ & $\mathrm{N}-\mathrm{O}-18$ & 62.9 & $\mathrm{Ob}-\mathrm{N} 1$ & 2.878 & $11-\mathrm{O}-\mathrm{N} 3$ & 121.5 \\
\hline$\left(\mathrm{Oa}-\mathrm{O} 1 \mathrm{~s}^{\mathrm{a}}\right.$ & $3.032)$ & $\mathrm{N}-\mathrm{O}-19$ & 125.4 & $\mathrm{Ob}-\mathrm{N} 3$ & 2.939 & $\mathrm{~N} 1-\mathrm{O}-\mathrm{N} 3$ & 103.6 \\
\hline \multirow[t]{3}{*}{$\left(\mathrm{Oa}-\mathrm{O} 19^{\prime \prime f}\right.$} & 2.99()$)$ & $20-O-18$ & 150.2 & & & & \\
\hline & & $20-O-19$ & 139.4 & & & & \\
\hline & & $18-O-19$ & 64.7 & & & & \\
\hline $\mathrm{O} 11-\mathrm{Ob}^{\prime \mathrm{d}}$ & 2.858 & $\mathrm{~b}-11-\mathrm{N} 3$ & 116.7 & $\mathrm{O} 14-\mathrm{N} 4$ & 2.905 & $\mathrm{~N} 4-14-\mathrm{N} 44^{\prime \prime \prime}$ & 112.3 \\
\hline O11-N3 & 2.911 & & & $\mathrm{O} 14-\mathrm{N} 4^{\prime \prime \prime h}$ & 2.935 & & \\
\hline$\left(\mathrm{O} 11-\mathrm{N} 4^{\prime d}\right.$ & $3.037)$ & & & & & & \\
\hline $\mathrm{O} 17^{\mathrm{a}}-\mathrm{N} 1$ & 2.867 & $\mathrm{~N} 1-17-\mathrm{N} 2$ & 101.6 & $\mathrm{O} 18-\mathrm{N} 2$ & 2.941 & $\mathrm{~N}-18-\mathrm{O}$ & 64.2 \\
\hline $\mathrm{O} 17^{\mathrm{a}}-\mathrm{N} 2^{\prime}$ & 2.899 & & & $\left(\mathrm{O} 18-\mathrm{Oa}^{\mathrm{b}}\right.$ & $3.032)$ & & \\
\hline O19-N3 & 2.903 & N3-19-N4 & 95.4 & $\mathrm{O} 20-\mathrm{N} 2 "$ & 2.807 & $\mathrm{~N}-20-\mathrm{O}$ & 104.6 \\
\hline $\mathrm{O} 19-\mathrm{N} 4^{\prime d}$ & 2.958 & & & $\left(\mathrm{O} 20-\mathrm{Oa}^{\prime}\right.$ & $3.023)$ & & \\
\hline$\left(\mathrm{O} 19-\mathrm{Oa}^{\prime \prime g}\right.$ & $2.990)$ & & & & & & \\
\hline
\end{tabular}

* Data of distances and angles between N1-N4, $\mathrm{Oa}$ and $\mathrm{Ob}$ and oxalatc oxygen atoms arc given, some of which are repeated for giving the angles at the oxygen atoms. Bonds placed between parentheses are considered less important. Approximate standard deviations are $0.013 \AA$ and $0.5^{\circ}$ respectively. The additional indices ${ }^{\mathrm{a}-\mathrm{h}}$ indicate atoms outside the cell or not "belonging" to the half tetramers within the cell. They represent the following transformations: (") $x-1, y, z$, (b) $x+1, y, z,\left(^{c}\right) 2-x, y-1 / 2,1 / 2-z,\left(^{d}\right) 1-x, y-1 / 2,1 / 2-z,\left(^{e}\right) x, 1 / 2-y, z-1 / 2,\left(^{f}\right) x-1,1 / 2-y, z-1 / 2,\left({ }^{8}\right) x+1,1 / 2-y, 1 / 2+z$, $\left({ }^{\mathrm{h}}\right)-\mathrm{x}, 1-\mathrm{y},-\mathrm{z}$. 
Planes of best fit through the oxalate groups have been calculated and are given in Table $V$, with the deviations of the atoms from the planes. It can be concluded that the displacements of the oxygen and titanium atoms are not within the range of experimental errors, so the atomic arrangements are definitely nonplanar. If the twist angles of $\mathrm{O}-\mathrm{C}-\mathrm{O}$ parts relative to each other are calculated, they turn out to be 9.1, 9.3, 7.3 and 11.0 degrees for the oxalate groups in the order $\mathrm{n}=0,2,6,8$, respectively.

It is remarkable that the deviations of especially the oxygen atoms (looking through columns) follow a pattern of up and down displacements in such a way that the first plane is somewhat similar to the fourth and the second to the third. In other words the direction of rotation angles of twisting can be defined negative, positive, positive, negative. The effect is not simply a matter of numbering, because the atoms in the columns have the same characteristic of e.g. long or normal Ti-O distance. Probably in this way the least steric hindering is achieved.

As could be expected, the oxalate "planes" are nearly perpendicular to each other within one titanium unit: the angles between plane 0 and 2 (defined without Ti) and between 6 and 8 are 86.5 and $92.2^{\circ}$ respectively. Plane 2 is nearly parallel with 6 (difference about $9.5^{\circ}$ ) and the angle between planes 0 and 8 is about $39.6^{\circ}$.

In Table VI hydrogen bond distances between terminal oxalate oxygen atoms and $\mathrm{NH}_{4}{ }^{+}$or $\mathrm{H}_{2} \mathrm{O}$ and some angles are given. Some of them have also been designated in Figure 1. There are four independent $\mathrm{NH}_{4}{ }^{+}$ions $\mathrm{N} 1$ to $\mathrm{N} 4$ and two $\mathrm{H}_{2} \mathrm{O}$ groups $\mathrm{Oa}$ and $\mathrm{Ob}$. Distances greater than $3.09 \AA$ have not been given in the table, thus the bridging oxygen atoms 05 (distance to nearest atom N3' $3.167 \AA$ ) and $\mathrm{O6}$ (to $\mathrm{N} 1^{\prime \prime} 3.112$, to N3" $3.129 \AA$ ) have not been included.

From the table it can be seen that the $\mathrm{NH}_{4}{ }^{+}$group $\mathrm{N} 1$ is the most perfectly surrounded by $\mathrm{O} 17^{\mathrm{a}}$ and the two water groups. With the other groups bent hydrogen bonds are apparently prevailing. The shortest distance turns out to be $2.81 \AA$, for $\mathrm{N} 2-\mathrm{O} 20^{\prime \prime}$; most of them are in the range of $2.86-2.96 \AA$.

It is interesting to note that within this range some of the terminal oxalate oxygen atoms have bifurcated connections to $\mathrm{NH}_{4}{ }^{+}$and/or $\mathrm{H}_{2} \mathrm{O}$. The forked hydrogen bonds appear to be linked to those oxygen atoms which already have relatively long bond distances to carbon (see also Table IV).

The ammonium groups $\mathrm{N} 1$ and $\mathrm{N} 3$ act as hydrogen donors towards the water molecules $\mathrm{Oa}$ and/or $\mathrm{Ob}$. $\mathrm{Ob}$ has a rather strong hydrogen bond to the oxygen atom O11' and weaker bonds to N1 and N3, while Oa, according to Tablc VI, must be more weakly bonded to its environment.

Because it was just this last water molecule which showed a rather high thermal parameter (Table II), it was decided to compare these features of the hydrogen bonding with some thermal analysis experıments. It was already known ${ }^{12,13}$ that on heating the compound the crystal water leaves in two steps, as is illustrated in Figure 5. The first half disappears quite easily between 30 and $80^{\circ} \mathrm{C}$, without disturbing the crystal structure. Determination of unit cell dimensions of crystals heated to $80^{\circ} \mathrm{C}$ (Table VII) showed that all cell parameters became smaller on heating, resulting in a reduction of cell volume by $1.6 \%$. Crystal species II apparently showed an incomplete removal of the first half of crystal water.

A Fourier synthesis (Figure 6) made by using the differences in structure factors of the same crystal before and after heat treatment showed a strong peak at the place of the water group $\mathrm{Oa}$, and nowhere else. This shows that it is this water molecule Oa, with the high thermal parameter, which is driven out upon heating at $80^{\circ} \mathrm{C}$ and is thus held to the crystal very loosely compared to the other crystal water group $\mathrm{Ob}$.

Calculation of the endothermic heat effects involved resulted in a value of $\Delta \mathrm{H}=26.8 \mathrm{~kJ} \mathrm{~mol}^{-1}$ for the second water loss. It was not possible to calculate the

TABLE VII. Variation of Unit cell Dimensions with Dehydration at $80^{\circ} \mathrm{C}$, at which Temperature Half of the Crystal Water was Removed.

\begin{tabular}{|c|c|c|c|c|c|c|c|c|}
\hline \multirow{2}{*}{$\begin{array}{l}\text { Crystal } \\
\text { specimen }\end{array}$} & \multicolumn{2}{|l|}{ a } & \multicolumn{2}{|l|}{$\mathrm{b}$} & \multicolumn{2}{|l|}{$\mathrm{c}$} & \multicolumn{2}{|l|}{$\beta$} \\
\hline & $\begin{array}{l}\text { With } \\
\mathrm{H}_{2} \mathrm{O}\end{array}$ & $\begin{array}{l}\text { With } \\
1 / 2 \mathrm{H}_{2} \mathrm{O}\end{array}$ & $\begin{array}{l}\text { With } \\
\mathrm{H}_{2} \mathrm{O}\end{array}$ & $\begin{array}{l}\text { With } \\
1 / 2 \mathrm{H}_{2} \mathrm{O}\end{array}$ & $\begin{array}{l}\text { With } \\
\mathrm{H}_{2} \mathrm{O}\end{array}$ & $\begin{array}{l}\text { With } \\
1 / 2 \mathrm{H}_{2} \mathrm{O}\end{array}$ & $\begin{array}{l}\text { With } \\
\mathrm{H}_{2} \mathrm{O}\end{array}$ & $\begin{array}{l}\text { With } \\
1 / 2 \mathrm{H}_{2} \mathrm{O}\end{array}$ \\
\hline \multirow[t]{2}{*}{ I } & \multirow[t]{2}{*}{13.476} & & \multicolumn{2}{|l|}{11.329} & \multirow[t]{2}{*}{17.649} & & \multirow[t]{2}{*}{126.68} & \\
\hline & & 13.395 & & 11.259 & & 17.478 & & 126.29 \\
\hline \multirow[t]{2}{*}{ II } & \multirow[t]{2}{*}{13.471} & & \multirow[t]{2}{*}{11.329} & & \multirow[t]{2}{*}{17.643} & & \multirow[t]{2}{*}{126.65} & \\
\hline & & 13.429 & & 11.280 & & 17.545 & & 126.47 \\
\hline \multirow[t]{2}{*}{ III } & \multirow[t]{2}{*}{13.473} & & \multirow[t]{2}{*}{11.331} & & \multirow[t]{2}{*}{17.646} & & \multirow[t]{2}{*}{126.66} & \\
\hline & & 13.396 & & 11.267 & & 17.483 & & 126.29 \\
\hline
\end{tabular}




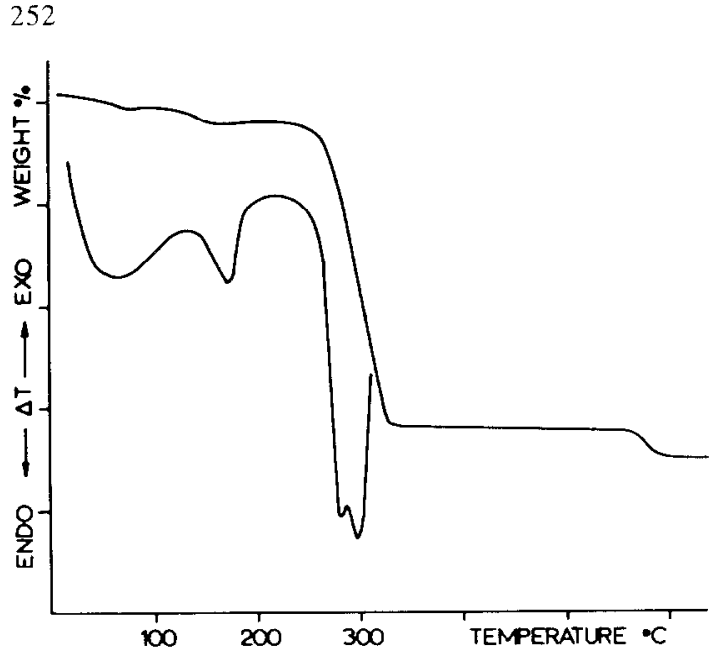

Figure 5. TGA and DTA curves for decomposition of $\left(\mathrm{NH}_{4}\right)_{2}$ $\mathrm{TiO}\left(\mathrm{C}_{2} \mathrm{O}_{4}\right)_{2} \cdot \mathrm{H}_{2} \mathrm{O}$. Heating rate $10^{\circ} \mathrm{C} / \mathrm{min}$.

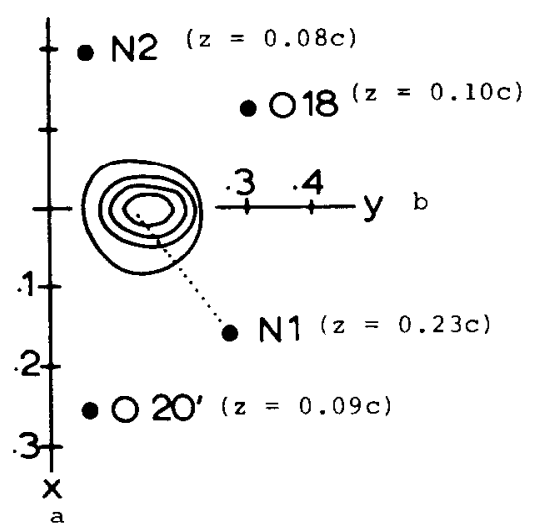

Figure 6. The $\mathrm{H}_{2} \mathrm{O}$ group $\mathrm{Oa}$ at section $\mathrm{z}=0.05 \mathrm{c}$ between some neighbouring atoms, as revealed by a difference Fourier synthesis, using structure factors of the same crystal with and without half of the crystal water.

corresponding heat effect for the first water molecule. However, it could be qualitatively deduced from the DTA results that the heat effect was decidedly smaller, which together with the lower decomposition temperature confirms the difference in bond strength with which the two water groups $\mathrm{Oa}$ and $\mathrm{Ob}$ are held.
G. M. H. van de Velde, S. Harkema and P.J. Gellings

\section{Acknowledgements}

The authors are deeply indebted to Miss M.M.A. Perik, A.B. van Egmond and G.J. van Hummel for their helpful assistance.

\section{References}

1 R.J.H. Clark, The Chemistry of Titanium and Vanadium, Elsevier, Amsterdam, 1968.

2 J.A. Iber's, Nature, 197, 686 (1963).

3 G.D. Smith, Ch. N. Caughlan and J.A. Campbell, Inorg. Chem., 1l, 2989 (1972).

4 G. Lundgren, Arkiv Kemi, 10, 397 (1957); Svensk. Kem. Tidskr., 71, 200 (1959).

5 G.E. Form, E.S. Raper, R.E. Oughtred and H.M.M. Shearer, Chem. Comm., 945 (1972).

6 G.M.II. van de Velde, S. Harkema and P.J. Gellings, Inorg. and Nucl. Chem. Letters, 9, 1169 (1973).

7 A.B. van Egmond, internal publication, 1973, Chem. Physics Laboratory, Twente University of Technology.

8 R.B.K. Dewar, Crystallographic Computing, Ed. F.R. Ahmed, Munksgaard, Copenhagen, 1970, p. 63.

9 W.R. Busing, K.O. Martin and H.A. Levy, ORFLS, ORNL-TM-305, 1962, Oak Ridge National Laboratory, Tennessee.

10 A.J. Freeman and R.E. Watson, Acta Cryst., 14, 231 (1961).

$11 \mathrm{~S}$. Harkema, Electron Density and $X-K$ ay Diffraction, Ph. D. Thesis, 1971, Chapter V. Twente University of Technology.

12 H. A. Papazian, P.J. Pizzolato and J.A. Patrick, J. Am. Cer. Soc., 54, 250 (1971).

13 G. M.H. van de Velde and P.J.D. Oranje, to be published.

14 STEREO computer program written by B.W. van de Waal, Chemical Physics Laboratory, Twente University of Technology, Enschede, Netherlands.

15 C.K. Johnson, ORTEP ORNL-3794, 1965, Oak Ridge National Laboratory, Tennessee.

16 A.C. Skapski and P.G.H. Troughton, Acta Cryst., 26B, $716(1970)$.

17 Chao-Yang Hsu and M. Orchin, J. Chem. Educ., 50, 114 (1973)

18 N.W. Alcock, J. Chem. Soc. Dalt. Trans. (1973), 1610.

19 H. Küppers, Acta Cryst., 29B, 318 (1973). 